\title{
Drought in Brazil: a hidden Public Health Disaster
}

\section{Davison (Donald Davison)}

Health Administration \& Human Resources,

$4^{\text {th }}$ Floor McGurrin Hall, Scranton, PA 18510-4699

\section{E-mail address:}

donald.davison@scranton.edu

\section{Reprint address:}

Health Administration \&

Human Resources

$4^{\text {th }}$ Floor McGurrin Hall

Scranton, PA 18510-4699

Suource: Clinical Social Work and Health Intervention

Volume: 7

Issue: 4

Pages: $12-19$

Cited references: 13

\section{Reviewers:}

Doc. Dr. Gabriela Lezcano, Ph.D.

University of California, San Francisco, USA

e-mail: gabikak@gmail.com

doc. PhDr. Jiří Tůma, PhD.

VŠTVS Palestra v Praze, CZ

e-mail: jirkatuma@centrum.cz

\section{Key words:}

Climate change, Healthcare, Brazil, Population.

\section{Publisher:}

International Society of Applied Preventive Medicine i-gap

CSWHI 2016; 7(4): 12 - 19; DOI 10.22359/cswhi_7_4_02 @ 2016 Clinical Social Work and Health Intervention

\section{Abstract:}

Climate change has increased the likelihood of extreme weather events; drought being one of them. Between 1990 and 2014, drought accounted for only $8.7 \%$ of the reported natural disasters in Brazil (Basic 2015). However, $58.4 \%$ of economic issues related to natural disasters were drought related (Basic 2015). For the healthcare community of Brazil, economic crunches tighten government spending. The impact of droughts is difficult to document due to no assigned start and finish, 
with the effects accumulating slowly over time. Although great progress has been made to reduce social and economic vulnerability, Brazil must look at reviewing current programs, particularly in public health, and begin planning of new intervention with local communities. This paper aims to discuss the droughts impact on Brazil's population and to provide a planning baseline for healthcare professionals and government officials to alleviate the impact of drought for a population already living within a vulnerable environment.

\section{Drought Overview}

Brazil has been called the "Saudi Arabia of water," having an abundance of the resource that other emerging national economies (BRICS) have issues with. With just 5.7\% of the world's landmass, $20 \%$ of the world's freshwater flows through the Amazon basin within Brazil. However, as rainfall dwindles, populations and usage increase, and infrastructure breaks down, a more frightening situation is unfolding: the taps are running dry. Recently, 2012-2015, drought has reached the most populated city in the Americas and the surrounding state of São Paulo (Figure 1). The drought afflicting this area for three years has become the worst since the 1920s.
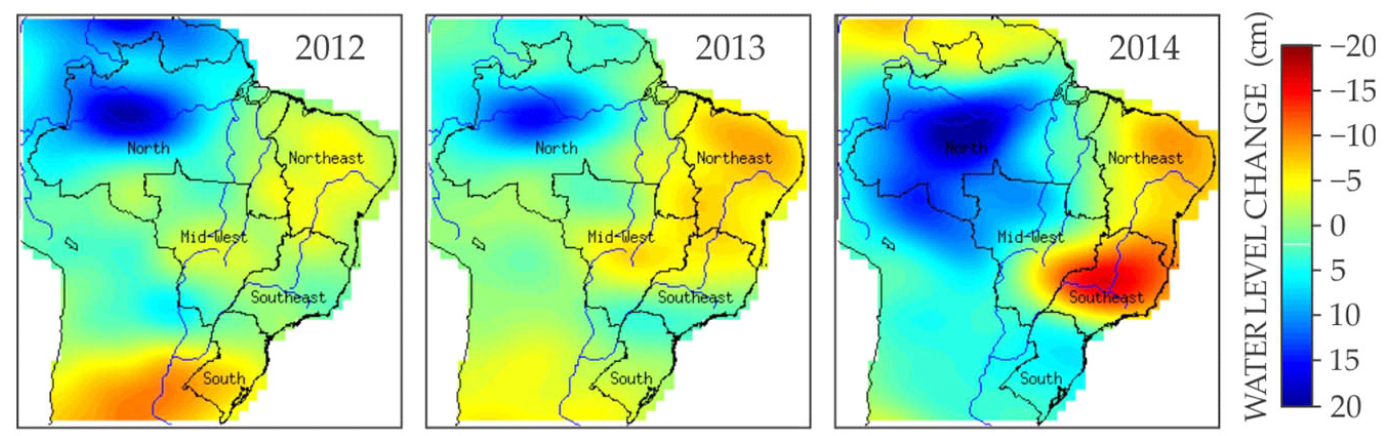

Figure 1 South American Water Levels from NASA's Gravity Recovery and Climate Experiment Spacecraft (Day, 2015)

Aside from São Paulo, a large portion of Northeast Brazil falls within the semi-arid zone. This region has a significant susceptibility to extreme drought events, particularly due to the low amount of annual rainfall and a concentration of the rainfall that it does receive over a few months per year.

\section{Causes}

The precise time of a drought's onset or end are not easily defined. Unlike sudden/ rapid emergencies such as earthquakes, tsunami's or floods, droughts are slow/insidious emergencies that appear without showing visible impacts in the short term. As a climatological event, impacts of drought depend greatly on human activities, and can be exasperated by social vulnerability. Drought is a natural disaster that generates many second and third order effects. Health implications can be numerous and far reaching. 
in $\mathrm{CO}_{2}$ within the atmosphere can lead to warmer conditions which subsequently lead to more evaporation and precipitation overall, individual regions will vary with some becoming wetter and others dryer. Known as evapotranspiration, the trees in Amazon rainforest not only remove $\mathrm{CO}_{2}$ from the atmosphere but also release vast amount of water vapor, creating so called flying rivers that subsequently fall as rain. These flying rivers create a low-pressure system that sucks in air surrounding it eventually and continually pumping moisture inland from the ocean. Deforestation degrades the low pressure systems, essentially turning off the pump. Thus, large-scale deforest-ation is believed to be a major contributor to the most recent drought in South-eastern Brazil. The impact of the atmospheric block within the Amazon rainforest and the impact it's made on precipitation in Brazil is depicted in Figure 2 below.

\section{Infrastructure}

For every ten liters treated by the Basic Sanitation Company of São Paulo State in 2012, three are not consumed or used on a regular basis (Leita 2014). These losses occur because of leaks in the distribution; illegal connections; theft; lack of measurement. In comparison, the best systems in the world such as Japan and Germany lose around $8 \%$. São Paulo is not the only city/ state experiencing water loss issues. The average Brazilian cities lost $36.9 \%$ of treated water between the treatment plant and consumer faucets in 2012 (Leita 2014).

\section{Human Activities}

The average Brazilian citizen uses 187 liters per day (DATA, 2014), way above the World Health Organization's guideline of 100. This high usage coupled with population

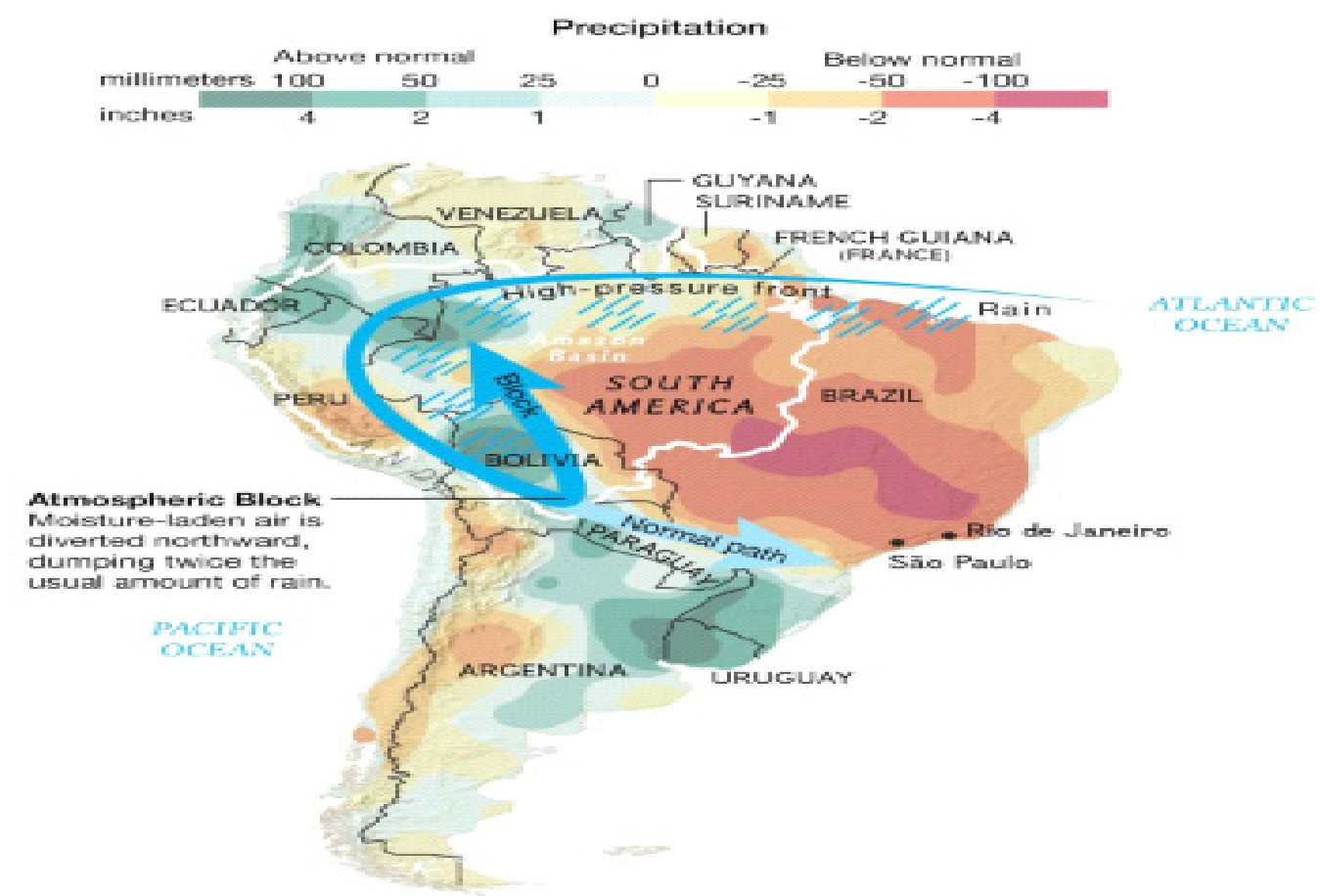

Figure 2 Altered Rain Patterns in South America Linked to Deforestation (Foster, 2015) 
growth has put the outdated reservoirs supplying the populated cities at very high water stress levels.

To add to the infrastructure woes, the water systems that supply a majority of São Paulo and other major urban areas were constructed between 1960 and 1980. From Figure 3 and Figure 4 below, the population growth in Brazil and urban areas has increased at an astounding rate from the time of construction.

\section{Population Growth:}

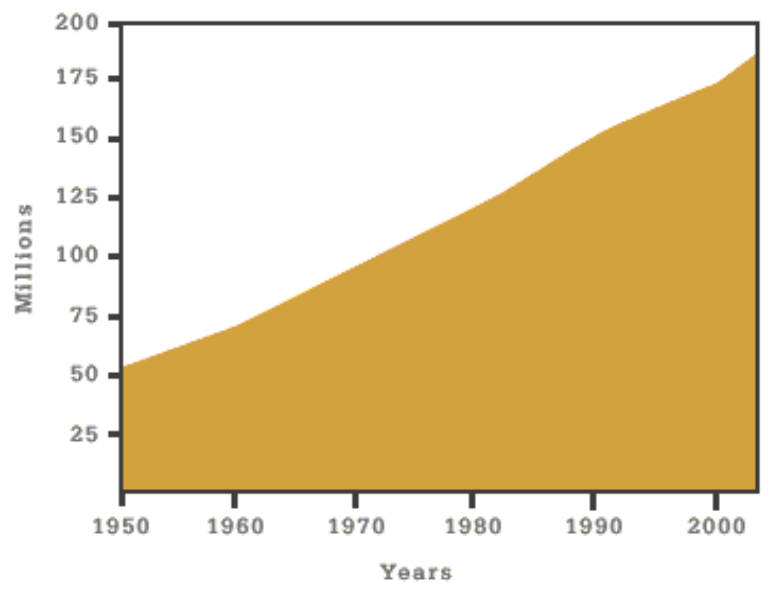

Figure 3 Population Growth in Brazil (Brito, 2006)

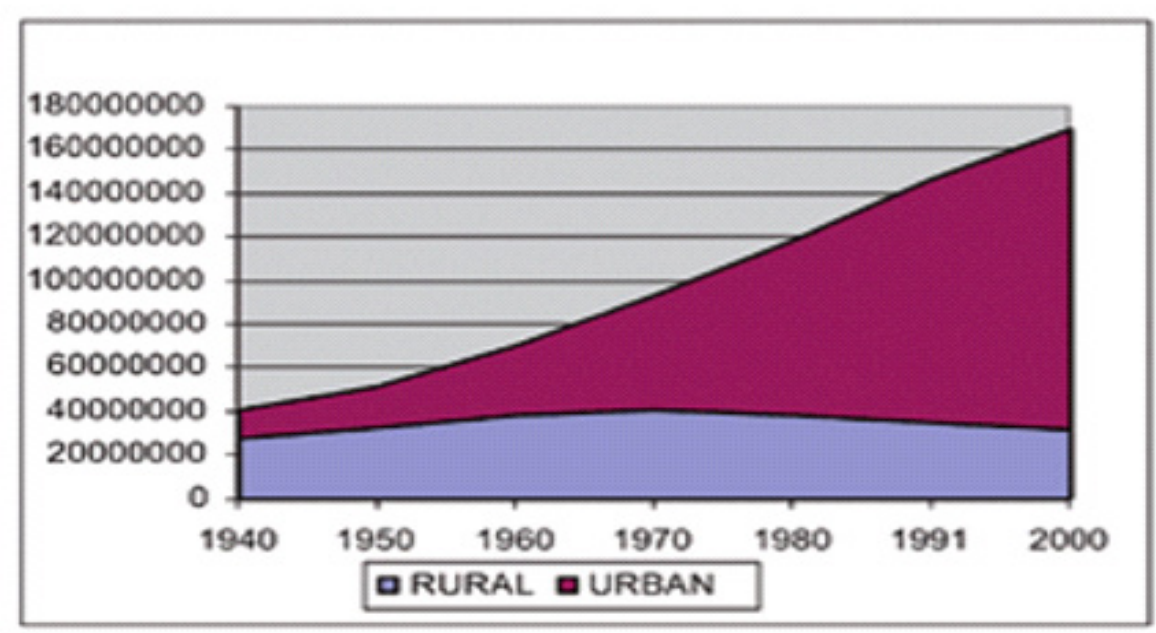

Figure 4 Population Growth in Rural \& Urban Brazil (Brito, 2006) 


\section{Health Risks}

The health risks associated with the most recent drought to plague Southeastern Brazil have yet to be determined. However, studies from droughts all over the world and Northeastern Brazil have created a baseline for what public health issues to expect. Drought can have impacts on known health risks such as inadequate or unsafe water for consumption and sanitation; increased population displacement; disruption of local health services (Sena 2014). Inadequate or unsafe water can lead to acute gastrointestinal issues; water-borne and food-borne diseases; reduced crop yields; death of livestock; infectious and parasitic diseases; skin infections. Local healthcare services can be greatly impacted as the loss of power, loss of medicines and personnel, and infection control becomes issues. Brazil and poorer regions of cities in particular could be prone to water outages and electricity loss as $75 \%$ of the electric power supply comes from hydroelec-tricity (EIA 2014).

Drought also asserts itself in acute and chronic health effects including malnutrition; vector-borne diseases; communicable diseases; respiratory conditions; psycho-social stress; mental health disorders (Sena 2014). Vector-borne diseases such as Dengue, Chikungunya, and the Zika Virus are spread via mosquitoes. It may seem that mosquito populations and viruses spread by them would dwindle as water becomes scarcer. However, the opposite is occurring in low income and rural areas within Brazil. In the poorer areas of Recife, Brazil, the lack of running water means residents have to store their own, creating potential mosquito breeding grounds. This is a common practice across many low income areas in Brazil.

One virus in particular, Zika, has received much attention in the Americas. Recently, in Brazil, local health authorities have observed an increase in Zika virus infections in the general public as well as an increase in babies born with microcephaly in northeast Brazil. Agencies investigating the Zika outbreaks are finding an increasing body of evidence about the link between Zika virus and Microcephaly. However, more investigation is needed before we understand the relationship between microcephaly in babies and the Zika virus. As recently as January 15, 2016, the United States Center for Disease Control and Prevention has issues a travel alert and out of abundance of caution, advised pregnant women to consider postponing travel to areas where Zika virus transmission is ongoing (CDC 2016).

\section{Government Intervention \& Plans Going Forward}

The 2015 United Nations Climate Change Conference held in Paris, France, from 30 November to 12 December 2015 provided a forum for world leaders to develop an agreement on the reduction of climate change. In preparation for the conference, Brazil submitted a six page plan that would contribute towards achieving the objective in reducing climate change impacts across the globe. Brazil highlighted its plan in mitigation; adaptation undertakings; implementation; and further clarified how its contribution will be implemented and upheld.

Brazil's contribution to tackle global climate change is to reduce greenhouse gas emissions by $37 \%$ below 2005 levels by 2025. Subsequent indicative contributions include reducing greenhouse gas emissions by $43 \%$ below 2005 levels by 2030 . Additionally, Brazil seeks to enhance its national capacity in water security and conservation and sustainable use of biodiversity. Furthermore, the plan enforces the implementation of the Forest Code at all levels of government. Thus, enforcing the protection and 
restoration of 12 million hectares of forests by 2030 (Federative, 2015).

\section{Impact on Healthcare Community}

The healthcare community must learn from any emergency or disaster, adopting plans to mitigate the impact for the next event. Disaster plans related to drought should aim to alleviate social vulnerability by seeking to build climate resilience, reduce economic and social losses, and alleviate poverty in drought-affected regions. A comprehensive approach that includes prevention and mitigation, preparedness, response, and recovery requires an active partnership between all relevant agencies and authorities. coordinating with key partners and stakeholders in drought efforts. Identifying atrisk populations for different drought-related implications will be vital in providing the proper care at the right place and time. Strategies and recommendations for mitigation and response to drought should be communicated to the target audience (UNISDR, 2009).

Disaster preparedness is a continual process that requires plans to be dynamic in order to learn from past events and to be effective. Training needs to be done regularly and the plan should be reviewed and amended in light of each occurrence. Drought may not

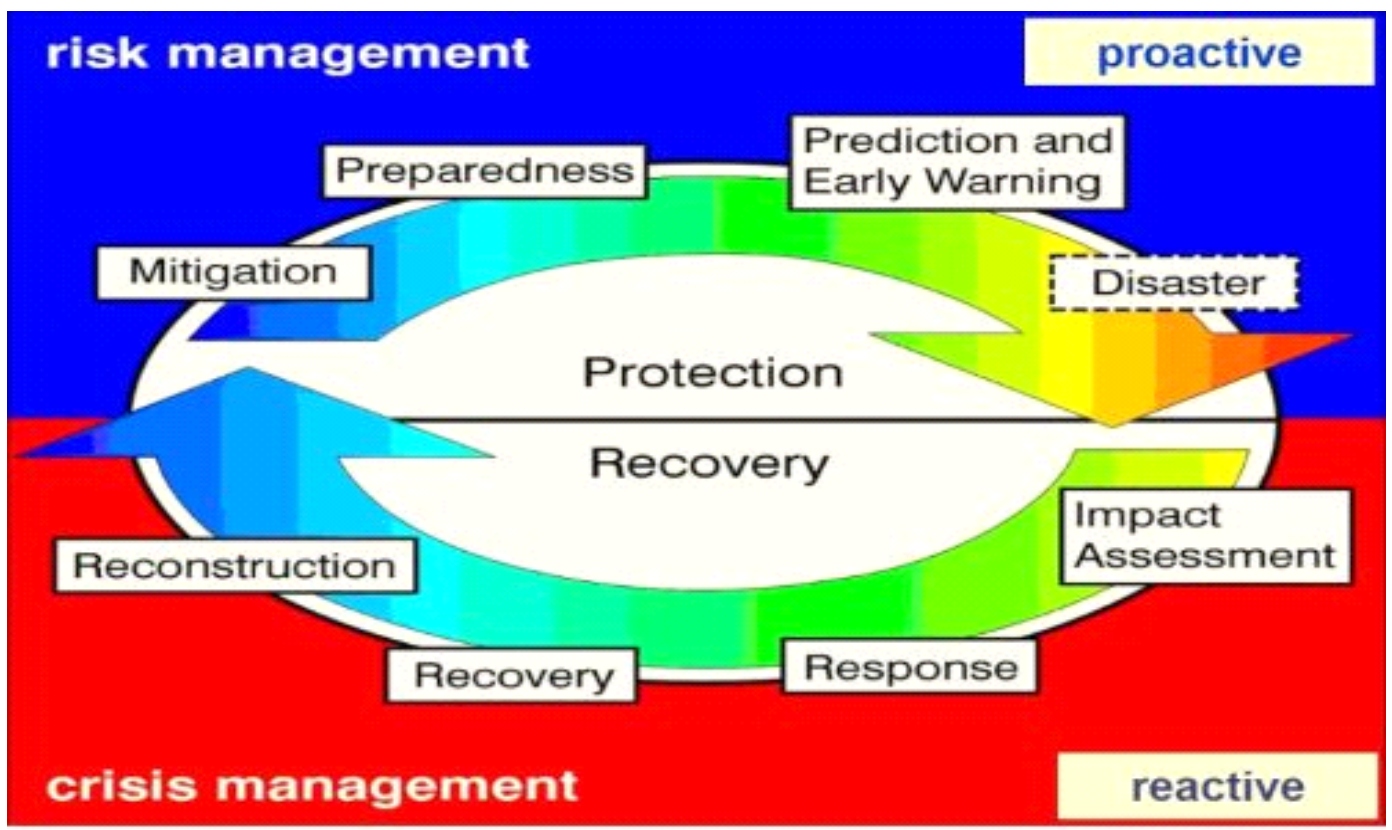

Figure 5 The cycle of disaster management (Pischke, 2014)

Disaster mitigation in the healthcare community includes: conducting an internal capacity assessment; participating in a jurisdiction-wide hazard and vulnerability assessment; conducting a public health vulnerability assessment; identifying and require a quick response like acute emergencies. However, the power issues, worker health, public health, and diseases should be documented in the event an area becomes drought stricken in the near future. 
The onset of Zika and the potential association with increased microcephaly cases has also reignited Brazil's abortion debate. Brazil's abortion laws make the procedure illegal under most circumstances. The only deviation from the abortion law is when a fetus is developing with anencephaly, a rare condition in which the baby is missing parts of its brain and skull or if a woman is raped. Decisions to legalize abortion due to microcephaly are complicated because doctors can only detect the deformities around the end of the second trimester and often the doctors cannot say what the effects will be if a baby is born with the issue.

The sudden uptick in microcephaly cases has reinvigorated a cadre of powerful women's rights activists in the country of Brazil. Wealthy Brazilian women pregnant with babies suffering from severe microcephaly or fetal malformations have options to terminate their pregnancies. These options include working with a private clinic to perform a safe abortion or hiring an attorney to make their case to a local legal tribunal. Poorer Brazilian women do not have this luxury and are afforded fewer options. Low income women seek illegal, dangerous abortions that can cause serious injuries or death.

\section{Conclusion}

Brazil is comprised of four major different areas, all in contrast of each other. Two of these regions, the Northeast and South experience droughts. In the Northeast, drought is a constant threat and the water supply struggles to sustain the population of 40 million people living in oppressive poor conditions. In the South, where the industrial and financial centers are located, excessive consumption and pollution has decreased the available water supply to the populations. These regions of Brazil present important challenges in the healthcare community. Collaboration between climate services and health services are important to strengthen risk management actions.

Even though drought is different from other natural disasters, it does not mean planning and actions should occur to help protect a community from the effects. Public health agencies across Brazil should be prepared to address public health impacts of drought within their communities at all times. Many aspects of drought have been well researched in the developed world, although there is still much to be learned about its public health implications. Epidemiologic and other studies must be conducted to provide stakeholders with drought-related data pertaining to short and long-term impacts of drought on health and the direct and indirect health effects that water shortages have on different population segments.

\section{References}

1. Basic Country Statistics and Indicators Brazil. PreventionWeb. 2015. Web. 9 Feb. 2016. <http://www.preventionweb.net/countries/bra/data/ $>$.

2. Brito, Fausto The Displacement of the Brazilian Population to the Metropolitan Areas. 24 May 2006. Web. 9 Feb. 2016. $<$ http://www.scielo.br/pdf/ea/v20n57/ en_a17v2057.pdf $>$.

3. CDC Issues Interim Travel Guidance Related to Zika virus. (2016, January 17). Retrieved January 19, 2016, from http://www. cdc.gov/media/releases/2016/s0315-zika-virus-travel.html

4. DATA 360: Average Water Use Per Person Per Day. (2014, May 28). Retrieved February 7, 2016, from http://www.data360.org/ dsg.aspx?Data_Set_Group_Id=757

5. Day, C. (2015, December 03). Weighing Brazil's Drought From Space. Retrieved January 11, 2016, from http://scitation.aip. org/content/aip/magazine/physicstoday/ news/10.1063/PT.5.7224 
6. EIA (2014, June 17) Hydropower Supplies More Than Three-Quarters of Brazil's Electric Power. Retrieved February 7, 2016, from http://www.eia.gov/todayinenergy/detail.cfm?id=16731

7. Federative Republic of Brazil Intended $\mathrm{Na}$ tionally Determined Contribution Towards Achieving the Objective of the United $\mathrm{Na}$ tions Framework Convention on Climate Change. (2015).

8. Foster, B. (2015, February 27) Quirky Winds Fuel Brazil's Devastating Drought, Amazon's Flooding. Retrieved January 10, 2016, from http://news.nationalgeographic. com/news/2015/02/150226-drought-floodssouth-america-brazil-bolivia-flying-riversenvironment/

9. Janatová, M., Tichá, M., Gerlichová, M., Řeháková, T., Švestková, O., 2015: Terapie poruch rovnováhy u pacientky po cévní mozkové př́hodě s využitím vizuální zpětné vazby In: Rehabilitácia ISSN 0375-0922, Vol. 52, 2015, No 3, p. 140-148

10. Leita, I. (2014, August 27) Sabesp perde $36 \%$ da água e trata $52 \%$ do esgoto em SP, diz instituto. Retrieved February 7,
2016, from http://g1.globo.com/sao-paulo/ noticia/2014/08/sabesp-perde-36-da-aguae-trata-52-do-lesgoto-em-sp-diz-instituto. html (translated using Google Translate)

11. NASA Global Climate Change. (2016, January 26). Retrieved February 7, 2016, from http://climate.nasa.gov/causes/

12. Pischke, Frederik (2016, 9 Feb.) Facing Droughts - The Integrated Drought Management Programme (IDMP). AID \& INTERNATIONAL DEVELOPMENT FORUM. 09 Apr. 2014. Web...<http://www.aidforum.org/ food-security/facing-droughts-the-integrated-drought-management-programme-id$\mathrm{mp}>$.

13. Sena, A., \& Barcellos, C. (2014) Managing the Health Impacts of Drought in Brazil International Journal of Environmental Research and Public Health, 11.

14. UNISDR (2009, October 14). Disaster Risk Management and Planning for Hospitals and Healthcare Facilities. Retrieved February 7, 2016, from http://www.preventionweb.net/files/11214_FreeStateProvincedisasterriskmanage.pdf 